УДК 53.088:62 - $754.2(045)$

V. Apostolyuk

Institute of Aerospace Control Systems, National Aviation University, Kyiv

\title{
EXCITATION OF PRIMARY OSCILLATIONS IN MICROMECHANICAL VIBRATORY GYROSCOPES
}

\begin{abstract}
Mathematical models of an electrostatic comb-drive actuator used in many micro-electromechanical systems and primary oscillations excitation system for micromechanical vibratory gyroscopes are developed and studied in the paper. A simple approximate mathematical model is presented for the capacitances and electrostatic forces operating in interdigitated microstructures, which led to the formulation of the optimal excitation system operation modes. Based on the analysis of the non-linear capacities, design recommendations for the comb-drive structure were formulated. Obtained model allows the analysis of not only linear but also non-linear phenomena in the physics of such structures. Presented mathematical model is simple enough to be used instead of time-consuming numerical simulations as well as for the further improvements of micromechanical sensors performances.
\end{abstract}

Keywords: micromechanical gyroscopes, comb-drive, non-linear physics, excitation system.

\section{Introduction}

Micromechanical resonators have been extensively developed in the last decade for sensor applications in mechanical, chemical, physical, and biological areas. One such sensor is the Coriolis vibratory gyroscope $(\mathrm{CVG})$, which often is referred to as micromechanical gyroscope [1] with respect to its most commonly used fabrication technology and the resulting size. Relatively recently this type of inertial sensors received significant attention from the developers of different kinds of guided munitions due to its low-cost and high survivability, which is essential for the combat systems. For example, micromechanical gyroscopes are commonly accepted as the best choice for the cannon launched rockets used in modern tanks. From this prospective, further improvements of micromechanical gyroscopes performances is viewed to be necessary and highly requested problem in the industry. One way to improve performances of CVG is to increase efficiency and provide more stable operation of its primary oscillation excitation system, since these oscillations are then modulated with the measured angular rate [2].

Micromechanical gyroscopes, as well as many of the modern micro-electromechanical systems (MEMS), use interdigitated microstructures both as an actuating and sensing component. Photograph of the typical interdigitated microstructure, which is part of the micromechanical gyroscope excitation system, is shown in Figure 1.

Sometimes such interdigitated microstructures are referred to as electrostatic comb-drive, which was first demonstrated by Tang et al. [3, 4]. Rigorous theory of the comb-drive was developed for the electrostatic forces operating on this actuator with and without the presence of a ground plane by Johnson and Warne [5].

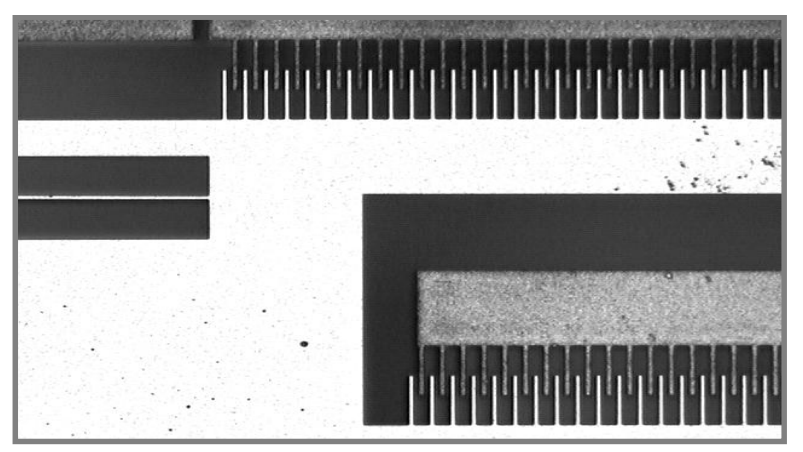

Fig. 1. Comb-drive of micromechanical gyroscope

However, currently developed theories of the interdigitated microstructures that enable the analysis of non-linear effects are quite complicated. As a result, designers of MEMS still have the tendency to use numerical finite element method (FEM) simulations in order to model micro-systems with electrostatic combdrives. Despite increased computational capabilities of the modern computers, complete FEM calculations still remain extremely time consuming. In order to improve the time performances of the FEM simulations, some approximate methods were developed, specifically macromodelling (see Gabbay and Senturia, [6]).

Nevertheless, numerical approaches do not allow analytical analysis of the comb-drive based excitation systems. Hence problem of creating simple approximate approach to analyse the comb-drive based excitation systems to account for the essential for micromechanical gyroscopes performances non-linear effects is addressed in this paper.

\section{Primary oscillations excitation system}

Let us first consider operation of the primary oscillation excitation system. Circuit in the figure 2 can describe general method of the resonator driving by means of the comb-drive. 


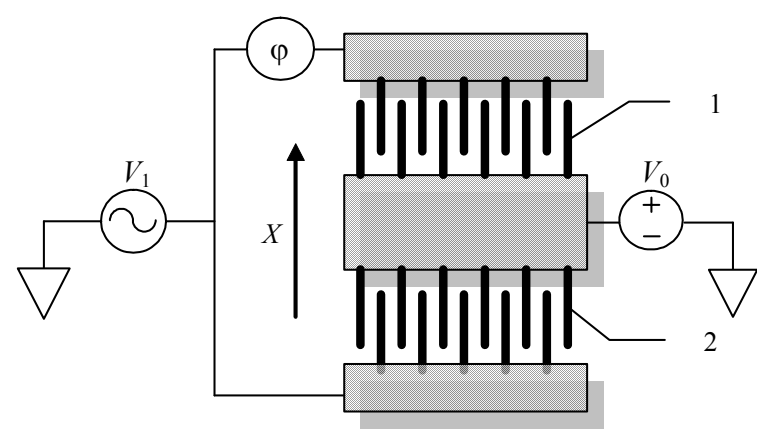

Fig. 2. Resonator driving principle

Here $V_{1}$ is the voltage applied to stators (fixed parts) of the comb drive 1 and 2, $V_{0}$ is the bias voltage applied to the inner moving mass, $\varphi$ is the phase shift between voltages applied to the first and second comb drive. Total electrostatic force acting on the mass along the $X$ axis in this case can be determined as

$$
F_{x}=\frac{\left(V_{1}(\tau+\varphi)-V_{0}\right)^{2}}{2} \frac{d C_{1}}{d x}+\frac{\left(V_{1}(\tau)-V_{0}\right)^{2}}{2} \frac{d C_{2}}{d x},
$$

where $C_{1}$ and $C_{2}$ are the capacitances of the comb drive 1 and 2 (fig. 2) respectively, $x$ is the displacement of the mass along the corresponding axis, $\tau$ is the phase of the driving voltage $V_{1}$. In case of the symmetrical and linear comb drives, where capacitances at the tips are negligible $d C_{1} / d x \approx-d C_{2} / d x=d C / d x \approx$ const and the force (1) will become

$$
F_{x}=\frac{1}{2}\left[\left(V_{1}(\tau+\varphi)-V_{0}\right)^{2}-\left(V_{1}(\tau)-V_{0}\right)^{2}\right] \frac{d C}{d x} .
$$

In micromechanical vibratory gyroscopes we usually want to have primary oscillations to have harmonic shape, to make demodulation process as accurate as possible. We can assume therefore that $V_{1}=V \sin (\omega t)$, $V_{0}=V \delta V$. As a result, expression (2) becomes

$$
\begin{aligned}
F_{x}= & \frac{V^{2}}{2}\left[(\sin (\omega t+\varphi)-\delta V)^{2}-\right. \\
& \left.-(\sin (\omega t)-\delta V)^{2}\right] \frac{d C}{d x} .
\end{aligned}
$$

It is apparent, that the only parameter capable of affecting the shape of the excitation force is the phase shift $\varphi$ between voltages on the comb-drives. Let us determine this phase shift from the maximum efficiency criterion. If the driving force does not depend on the displacement $x$, efficiency of the comb drive can be evaluated as

$$
\begin{aligned}
P(\delta V, \varphi) & =\int_{0}^{2 \pi}\left[F_{x}(\tau)\right]^{2} d \tau \\
& =\frac{\pi}{2}\left(1+8 \delta V^{2}+\cos (\varphi)\right) \sin ^{2}\left(\frac{\varphi}{2}\right) \times \\
& \times\left(V^{2} \frac{d C}{d x}\right)^{2} .
\end{aligned}
$$

Graph of the efficiency (4) is shown in fig. 3.

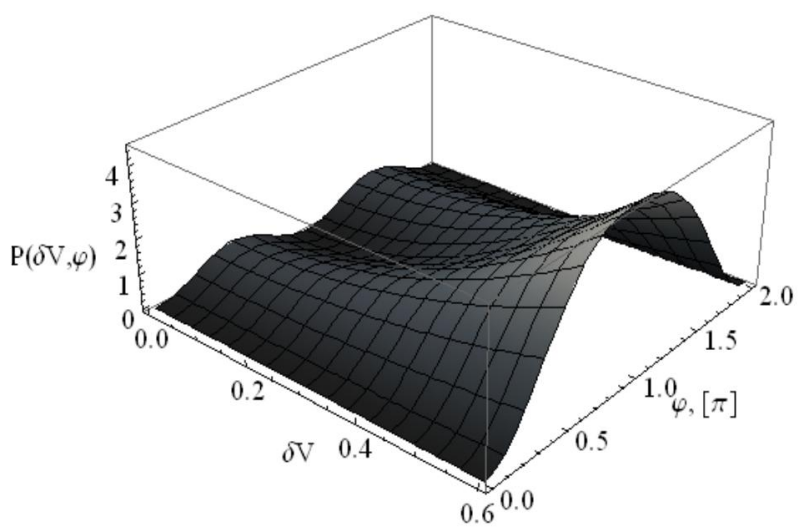

Fig. 3. Comb-drive efficiency

Analysing graph in Fig. 3, one should clearly see different optimal modes of excitation corresponding to different values for bias voltage $\delta V$. Let us identify these modes.

Maximum efficiency values for the phase shift $\varphi$ and the voltage ratio $\delta V$ as a parameter can be determined from the following equation

$$
\frac{d P(\delta V, \varphi)}{d \varphi}=0 \Rightarrow\left(4 \delta V^{2}+\cos \varphi\right) \sin \varphi=0 .
$$

Solving equation (5) yields maximum efficiency phases given by the following equations:

$$
\begin{gathered}
\varphi=\arccos \left(-4 \delta V^{2}\right),\left(\delta V<\frac{1}{2}\right), \\
\varphi=\pi,\left(\delta V \geq \frac{1}{2}\right), \\
\varphi=\frac{\pi}{2},(\delta V=0) .
\end{gathered}
$$

Efficiency plot for the maximum efficiency modes given by the different bias voltages in expressions (6) is shown in Fig. 4.

It is apparent that there are two different optimal phase shifts for different values of the bias $\delta V$, leading to the two essentially different driving modes for the primary excitation: without bias voltage (grounded mass), and with bias, which is larger then a half of the driving voltage amplitude.

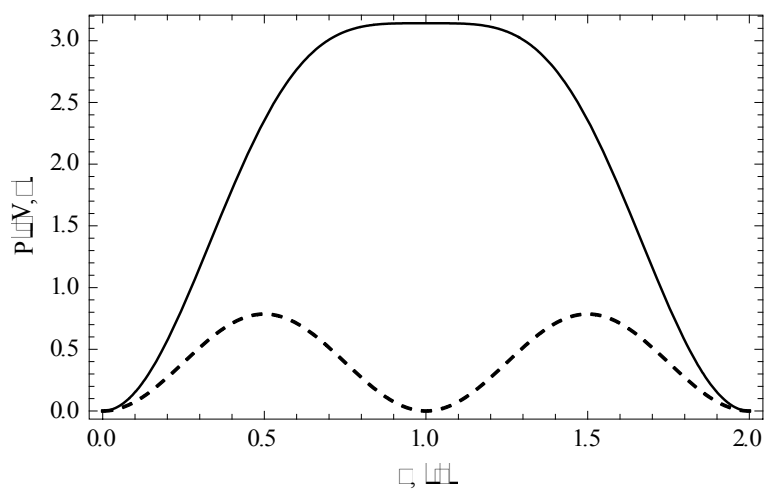

Fig. 4. Efficiency at different bias voltages (solid $-\delta V=0.5$, dashed $-\delta V=0$ ) 
Total electrostatic forces acting on the mass in these modes will be determined by means of the following formulae

$$
F_{x}=D(t) \frac{d C}{d x} .
$$

Here $D(t)$ is the driving function, which is different for the two modes and can be calculated as

$$
\begin{gathered}
D(t)=2 V^{2} \delta V \sin (\omega t), \quad \delta V \geq \frac{1}{2}, \\
D(t)=\frac{V^{2}}{2} \cos (2 \omega t), \quad \delta V=0 .
\end{gathered}
$$

It has to be noted that "biased" mode $(\delta V \geq 1 / 2)$ results in a larger driving force (higher efficiency) comparing with "grounded" mode $(\delta V=0)$. At the same time, driving force in the "grounded" mode will actuate with doubled frequency regarding to driving voltage frequency (see fig. 5).

This effect of doubling frequency leads to possibility to separate excitation voltage from the sensing in the frequency domain. As a result, better signal to noise ratios can be achieved.

\section{Comb-drive capacitance}

During all derivations presented above it was assumed that force doesn't depend on mass displacement. It means that $d C / d x \approx$ const, which is almost true for the small displacements. But in some applications of the comb drives it is necessary to achieve large displacement of the mass. The latter is often the case with the micromechanical gyroscopes, when higher amplitude of primary oscillations leads to higher sensitivity to the angular rate. In this case capacitance derivative is no longer constant and depends on displacements in a non-linear way.

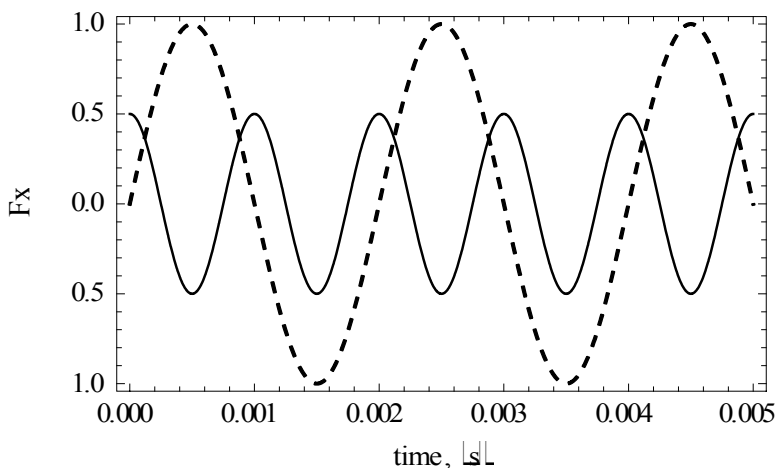

Fig. 5. Driving force in different modes (solid - "grounded" mode, dashed - "biased" mode)

Let us calculate capacitance for the comb structure cell that is shown in fig. 6 .

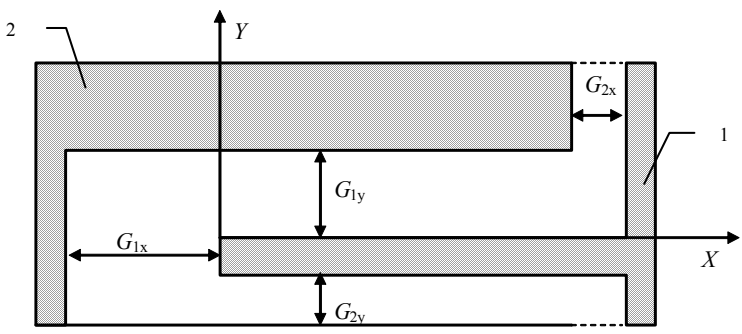

Fig. 6. Elementary comb-drive cell
There are four basic capacitances in this structure: $C_{i x}$ and $C_{i y}$ - between stator $(i=1)$ and mass $(i=2)$ in the $X$ and $Y$ direction respectively. Other dimensions are $L_{i}, B_{i}$ and $H$ - length, width and height of the combdrive finger. Initial position of the mass in the shown reference system will be defined by means of four gaps $G_{i x}$ and $G_{i y}$. If displacement of the mass relatively to stator will be defined by two variables $x$ and $y$ then corresponding capacitances will be

$$
\begin{gathered}
C_{1 x}=\frac{\varepsilon \varepsilon_{0} B_{1} H}{G_{1 x}-x}, C_{2 x}=\frac{\varepsilon \varepsilon_{0} B_{2} H}{G_{2 x}-x}, \\
C_{1 y}=\frac{\varepsilon \varepsilon_{0}\left(L_{0}+x\right) H}{G_{1 y}+y}, C_{2 y}=\frac{\varepsilon \varepsilon_{0}\left(L_{0}-x\right) H}{G_{2 y}-y} .
\end{gathered}
$$

Here $L_{0}$ is the initial overlapping length, such as $L_{0}=L_{2}-G_{1 x}=L_{1}-G_{2 x}$.

Total capacitance between mass and stator will be a sum of all capacitances:

$$
\begin{aligned}
C(x, y)= & C_{1 x}+C_{2 x}+C_{1 y}+C_{2 y}= \\
= & n \varepsilon \varepsilon_{0} H\left(\frac{B_{1}}{G_{1 x}-x}+\frac{B_{2}}{G_{2 x}-x}+\right. \\
& \left.+\frac{L_{0}+x}{G_{1 y}+y}+\frac{L_{0}+x}{G_{2 y}-y}\right) .
\end{aligned}
$$

Here $n$ is the total number of the elementary cells in the comb drive. Such capacitance will be no longer linear function of the displacements. Dependence of the capacitance from the displacements in $x$ direction is presented in fig. 7 .

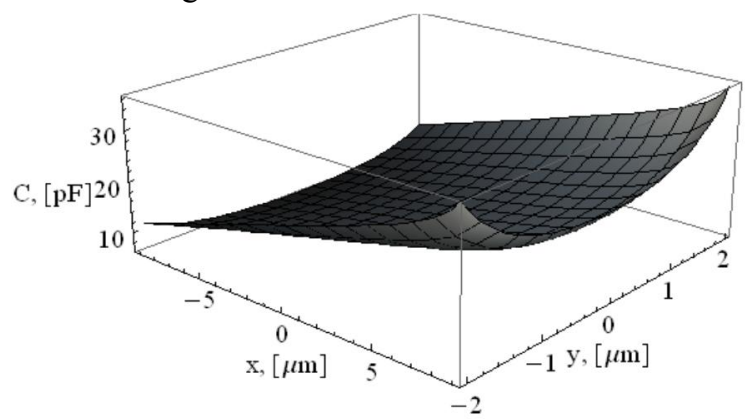

Fig. 7. Capacitance as a function of $\boldsymbol{x}$ and $\boldsymbol{y}$ displacements

Apparently, for large displacements both along $x$ and $y$ coordinates we observe non-linearity in the capacitance, given by the expression (10). In Fig. 8 one can see the section of the graph in Fig. 7 along the $x$ axis.

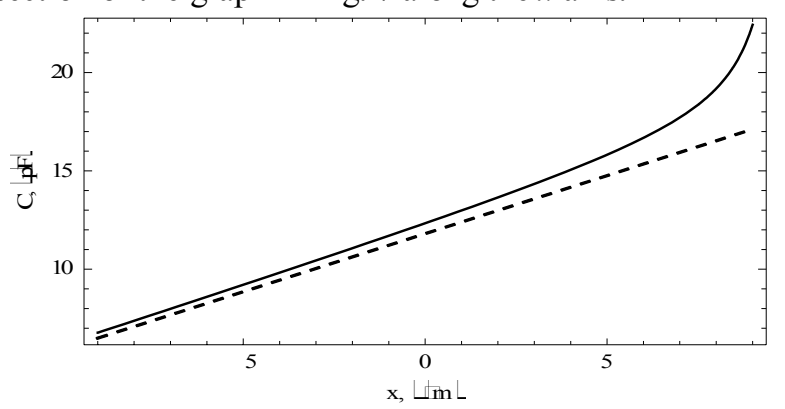

Fig. 8. Capacitance of the comb-drive (solid - non-linear, dashed - neglecting tip width) 
Here dashed line corresponds to the "linear" capacitance, where tip widths $B_{1}$ and $B_{2}$ in (10) were neglected (set to zero). From this graph one can see that "linear" capacitance approximation is noticeably different from the actual one.

With respect to (10), capacitances $C_{1}$ and $C_{2}$ in (1) for the symmetrical comb drive will be

$$
\begin{gathered}
C_{1}(x, y)=C(x, y), \\
C_{2}(x, y)=C(-x, y),
\end{gathered}
$$

and hence correspondent derivatives for the force (1) can be represented as follows

$$
\begin{aligned}
\frac{d C_{1}}{d x} & =H n \varepsilon \varepsilon_{0}\left[\frac{B_{1}}{\left(G_{1 x}-x\right)^{2}}+\frac{B_{2}}{\left(G_{2 x}-x\right)^{2}}+\right. \\
& \left.+\frac{1}{G_{1 y}+y}+\frac{1}{G_{2 y}-y}\right], \\
\frac{d C_{2}}{d x} & =-H n \varepsilon \varepsilon_{0}\left[\frac{B_{1}}{\left(G_{1 x}+x\right)^{2}}+\frac{B_{2}}{\left(G_{2 x}+x\right)^{2}}+\right. \\
& \left.+\frac{1}{G_{1 y}+y}+\frac{1}{G_{2 y}-y}\right] .
\end{aligned}
$$

Substituting in (1) derivatives with respect to displacement in y direction allows to calculate forces acting along $\mathrm{Y}$ axis as well. Corresponding derivatives are

$$
\begin{aligned}
& \frac{d C_{1}}{d y}=H n \varepsilon \varepsilon_{0}\left(L_{0}+x\right)\left[\frac{1}{\left(G_{2 y}-y\right)^{2}}-\frac{1}{\left(G_{1 y}+y\right)^{2}}\right], \\
& \frac{d C_{2}}{d y}=H n \varepsilon \varepsilon_{0}\left(L_{0}-x\right)\left[\frac{1}{\left(G_{2 y}-y\right)^{2}}-\frac{1}{\left(G_{1 y}+y\right)^{2}}\right] .
\end{aligned}
$$

Considering (12) one can see that displacements in the $x$ direction will result in changes of the force in $y$ direction as well. For some applications, such as comb driven micromechanical gyroscopes with double folded proof mass suspension, this will cause significant bias.

What else is important to note, is the absence of the overlapping length $L_{0}$ in the expression (11). This means, that actuation force does not depend on the overlapping length, while it is still present in the side force derivatives (12). From this point of view, introducing overlap diminishes influence of the primary oscillations on the quadrature mass motion.

\section{Excitation forces with non-linear capacitance}

Let us consider force in the $x$ direction for the non-linear capacitance comb drive. For the small displacements in $x$ direction we can approximate derivatives in (11) by linear dependencies

$$
\begin{gathered}
\frac{d C_{1}}{d x} \approx n H \varepsilon \varepsilon_{0}\left(a_{0}+a_{1} x\right), \\
\frac{d C_{2}}{d x} \approx-n H \varepsilon \varepsilon_{0}\left(a_{0}-a_{1} x\right),
\end{gathered}
$$

$$
\begin{gathered}
a_{0}=\frac{B_{1}}{G_{1 x}^{2}}+\frac{B_{2}}{G_{2 x}^{2}}+\frac{1}{G_{1 y}+y}+\frac{1}{G_{2 y}-y}, \\
a_{1}=2\left(\frac{B_{1}}{G_{1 x}^{3}}+\frac{B_{2}}{G_{2 x}^{3}}\right) .
\end{gathered}
$$

Thus net force acting on the mass in case of harmonic excitation with respect to (1) and (13) will be

$$
\begin{aligned}
F_{x} & =\frac{n H V^{2} \varepsilon \varepsilon_{0}}{2}\left[\left(a_{0}+a_{1} x\right)(\delta V-\sin (\omega t+\varphi))^{2}-\right. \\
& \left.-\left(a_{0}-a_{1} x\right)(\delta V-\sin (\omega t))^{2}\right]
\end{aligned}
$$

Results of the efficiency analysis of the non-linear comb drive are similar to those considered above. Graph in Fig. 9 demonstrates accuracy of the approximation (13) in comparison with the more accurate expressions (11) with respect to the sum of the capacitance derivatives for both comb-drives.

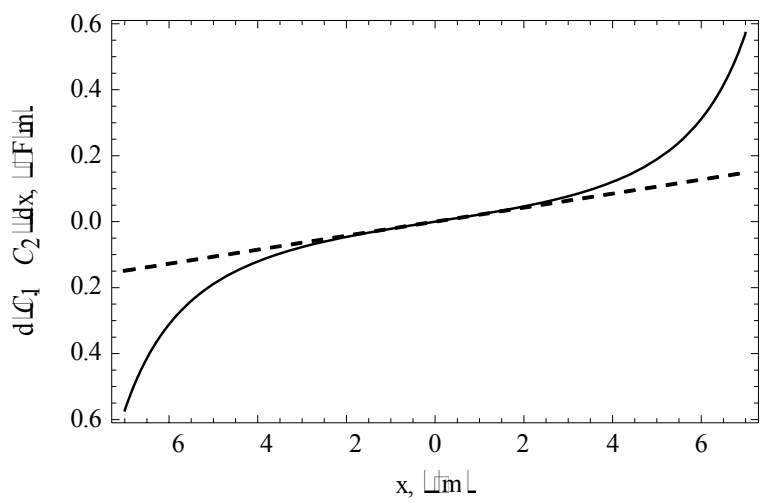

Fig. 9. Capacitance derivatives approximation (solid - non-linear derivative, dashed - linear approximation)

One should certainly note that the accuracy of the linear approximation is quite limited to the relatively small displacements.

Again there will be two optimal modes with the same phase shift. For the "biased" excitation mode

$$
\begin{aligned}
F_{x}= & n H V^{2} \varepsilon \varepsilon_{0}\left[2 a_{0} \delta V \sin (\omega t)+\right. \\
& \left.+a_{1}\left(\delta V^{2}+\sin ^{2}(\omega t)\right) x\right],
\end{aligned}
$$

and for the "grounded" mode

$$
F_{x}=\frac{n H V^{2} \varepsilon \varepsilon_{0}}{2}\left[a_{1} x+a_{0} \cos (2 \omega t)\right] .
$$

It has to be noted that for the biased excitation with large voltage ratio $\delta V$ non-linearity of the capacitances will cause significant natural frequency shift that cannot be neglected for some applications. In order to reduce influence of the non-linear effects it is necessary to increase gaps in the $x$ direction in comparison with the corresponding displacements.

Linear in terms of the displacement $x$ force essentially perturbs the natural frequency of the primary oscillation mode. For the "grounded" mode force given by the (16), the natural frequency receives a constant shift as 


$$
k_{*}=\sqrt{k^{2}-\frac{n H V^{2} \varepsilon \varepsilon_{0} a_{1}}{2 m}},
$$

where $k$ is the initial natural frequency related to the spring constant of the elastic suspension, $m$ is the mass of the sensitive element. Actual force acting on the sensitive element is shown in Fig. 10.

In case of the "biased" mode force (15), the natural frequency will be variable in time:

$$
k_{*}=\left[k^{2}-\frac{n H V^{2} \varepsilon \varepsilon_{0} a_{1}}{m}\left(\delta V^{2}+\sin ^{2}(\omega t)\right)\right]^{\frac{1}{2}} \text {. }
$$

Actual force in significantly non-linear mode for the "biased" excitation mode is shown in Fig. 11.

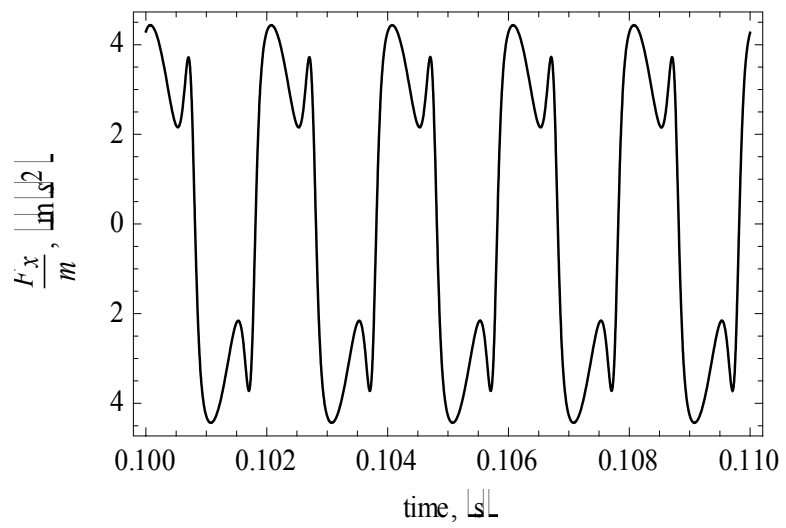

Fig. 10. Actual force acting on the sensitive element in the "grounded mode"

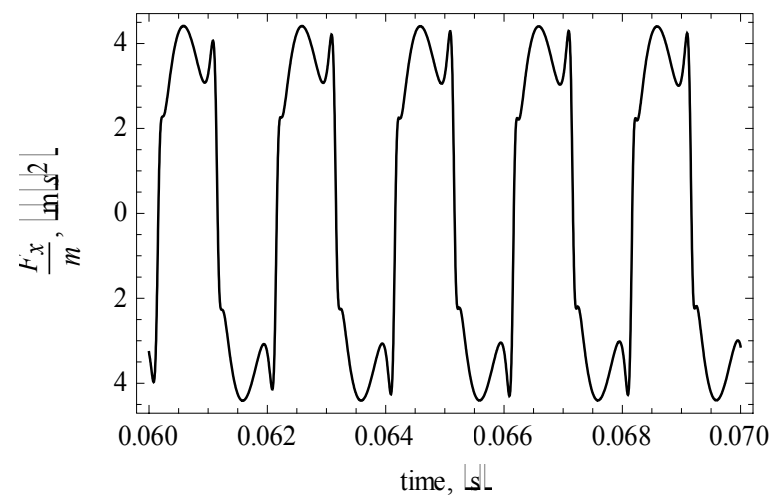

Fig. 11. Actual force acting on the sensitive element in the "biased mode"

Although forces in the figures 10 and 11 are far from being harmonic, after they are applied to the spring-mass-damper system of the sensitive element, the resulting oscillations are not that much different from the harmonic shape. This is the result of the natural filtering properties of the oscillator. Nevertheless, if almost ideal harmonic excitation is desired, the gaps between tips of the combs $G_{i x}$ must be chosen 3-5 times larger than the expected amplitude of primary oscillations, and excitation frequency must be adjusted according to the (17) and (18).

\section{Conclusions}

In the presented above research of the comb-drive based primary oscillations excitation system for micromechanical gyroscopes relatively simple mathematical model of the system has been developed. Based on the developed model, two essentially different excitation modes were found. Along with the non-linear capacitance model, simple approximate models for the excitation forces were obtained and analysed. As a result, combdrive design recommendations were formulated, that reduce undesired effect from the present in the system non-linearity. Derived mathematical model of the combdrive based excitation system allows analytical analysis of the micromechanical gyroscopes dynamics without necessity for the time consuming numerical simulations.

Since obtained in the paper model of the electrostatic side force clearly demonstrated unstable balance of the primary oscillations in $y$ direction, further study of the stability problems is viewed as a natural continuation to the presented above research.

\section{Acknowledgments}

Here I would like to express my deep and sincere gratitude to Ms. Veronika Kotlyarevska, who sacrificed a lot to make this research possible.

\section{References}

1. Yazdi N. Micromachined Intertial Sensors / N. Yazdi, F. Ayazi, K. Najafi // Proceedings of the IEEE. - 1998. - Vol. 86, No. 8. - P. 1640-1659.

2. Apostolyuk V. Theory and Design of Micromechanical Vibratory Gyroscopes / V. Apostolyuk // MEMS/NEMS Handbook (Ed: Cornelius T. Leondes), Springer. - 2006. - Vol.1, Chapter 6. P. 173-195.

3. Tang W.C. Laterally driven polysilicon resonant microstructures / W.C. Tang, T.H. Nguyen, and R.T. Howe // Tech. Dig. IEEE Micro Electro Mech. Syst. Workshop, Salt Lake City, UT. - Feb. 20-22, 1989. - P. 53-59.

4. Tang W.C. Electrostatic comb drive for resonant sensor and actuator application / W.C. Tang // Ph.D. dissertation, Univ. of California, Berkeley, CA. -1990.

5. Johnson W.A. Electrophysics of micromechanical comb actuators / W.A. Johnson, L.K. Warne // Journal of Microelectromechanical Systems. - 1995. - Vol. 4, No.1. P. 49-59.

6. Gabbay L.D. Automatic Generation of Dynamic MacroModels Using Quasi-Static Simulations in Combination with Modal Analysis / L.D. Gabbay, S.D. Senturia // Solid-State Sensor and Actuator Workshop (Hilton Head SC) . - 1998. P. 197- 220 .

Рецензент: доктор технічних наук, професор В.М. Азарсков, Інститут аерокосмічних систем управління, Національний авіаційний університет, Київ. 


\section{Збудження первинних коливань в мікромеханічних вібраційних гіроскопах}

\section{В.О. Апостолюк}

В иій статті було розроблено та вивчено математичні моделі електростатичного гребінчастого двигуна, який широко використовується у багатьох мікроелектромеханічних системах та системах збудження первинних коливань для мікромеханічних вібрачійних гіроскопів. Представлено просту наближену математичну модель для ємностей та електростатичних сил, діючих у зустрічно-цтирьових структурах, яка привела до знаходження оптимальних режсиів роботи системи збудження. На основі аналізу нелінійних ємностей було сформульовано рекомендації до проектування гребінчастих структур. Отримана модель дозволяє аналізувати не тільки лінійні, але і нелінійні феномени у фізиці таких структур. Представлена математична модель достатньо проста, щуоб ї̈ використовувати замість чисельного моделювання, що потребує багато часу, а також для подальшого покращення характеристик мікромеханічних сенсорів.

Ключові слова: мікромеханічний гіроскоп, гребінчастий двигун, нелінійна фізика, система збудження.

\section{Возбуждение первичных колебаний в микромеханических вибрационных гироскопах}

\section{В.А. Апостолюк}

В этой статье были разработаны и изучены математические модели электростатического гребенчатого двигателя, который широко используется во многих микроэлектромеханических системах и системах возбуждения первичных колебаний для микромеханических гироскопов. Представлено простую приближенную математическую модель для емкостей и электростатических сил, действующих во встречно-итыревых структурах, которая привела к нахождению оптимальных режимов работы системы возбуждения. На основе анализа нелинейных емкостей были сформулированы рекомендации к проектированию гребенчатых структур. Полученная модель позволяет анализировать не только линейные, но и нелинейные феномены в физике таких структур. Представленная математическая модель достаточно простая, чтобы использовать ее вместо занимающего много времени численного моделирования, а также для дальнейшего улучшения характеристик микромеханических датчиков.

Ключевые слова: микромеханический гироскоп, гребенчатый двигатель, нелинейная физика, система возбуждения. 